Edith Cowan University

Research Online

ECU Publications Post 2013

2-1-2018

\title{
Beyond 'know-what' and 'know-how' to 'know-who': enhancing human capital with social capital in an Australian start-up accelerator
}

Pi-Shen Seet

Edith Cowan University

Janice T. Jones

Lloyd Oppelaar

Graciela Corral De Zubielqui

Follow this and additional works at: https://ro.ecu.edu.au/ecuworkspost2013

Part of the Accounting Commons, and the Business Administration, Management, and Operations Commons

10.1080/13602381.2018.1431250

This is an Accepted Manuscript of an article published by Taylor \& Francis in Asia Pacific Business Review on February 2018, This is an Author's Accepted Manuscript of: Seet, P. S., Jones, J., Oppelaar, L., \& Corral de Zubielqui, G. (2018). Beyond 'know-what'and 'know-how'to 'know-who': enhancing human capital with social capital in an Australian start-up accelerator. Asia Pacific Business Review, 1-28. Available here.

This Journal Article is posted at Research Online.

https://ro.ecu.edu.au/ecuworkspost2013/4179 


\section{Beyond 'Know-What' and 'Know-How' to 'Know-Who' - Enhancing Human Capital with Social Capital in an Australian Start-up Accelerator}

Pi-Shen Seet ${ }^{\mathrm{a} *}$, Janice Jones ${ }^{\mathrm{b}}$, Lloyd Oppelaar ${ }^{\mathrm{bc}}$, Graciela Corral de Zubielqui ${ }^{\mathrm{d}}$

${ }^{a}$ School of Business and Law, Edith Cowan University, Joondalup, Australia

${ }^{b}$ Flinders Business School, Flinders University, Adelaide, Australia

${ }^{c}$ Community Living Australia, Strathalbyn, South Australia, Australia

${ }^{d}$ Entrepreneurship, Commercialisation and Innovation Centre, University of Adelaide, Adelaide, Australia

*corresponding author: p.seet@ecu.edu.au

\section{Original citation:}

Seet P-S., Jones, J., Oppelaar, L., Corral de Zubielqui, G., 2018. Beyond 'Know-What' and 'Know-How' to 'Know-Who' - Enhancing Human Capital with Social Capital in an Australian Start-up Accelerator. Asia Pacific Business Review. 24(2):233-260. DOI: $10.1080 / 13602381.2018 .1431250$ 


\section{Beyond 'Know-What' and 'Know-How' to 'Know-Who' - Enhancing Human Capital with Social Capital in an Australian Start-up Accelerator}

This study investigates the enhancement of human capital with social capital in a start-up accelerator and how this integration affects the entrepreneurial learning experience. In particular, it examines the relative importance of the three components 'know-what', 'know-how' and 'know-who'. The study involved thematic analysis of semi-structured interviews with participants in an Australian start-up accelerator that is delivered using ideas such as Design Thinking, the Business Model Canvas and Lean Start-up methodology. We find that although the programme emphasised 'know-what' and 'know-how', 'know-who' was most significant for participant learning. The results indicate that mentors and experts were especially helpful in shaping learning and in developing entrepreneurial networks. Moreover, our results show that the processes of 'know-what', 'knowhow' and 'know-who' are interrelated - by knowing 'who', participants learnt 'what' and 'how to' through social learning. The research contributes to entrepreneurial learning theory and application particularly in the Asia Pacific context, by providing evidence that 'know-who' closes the learning loop for 'know-what' and 'know-how' as 'know-who' can actually provide entrepreneurs with the means to enhance their entrepreneurial self-efficacy.

Keywords: Start-up accelerator; entrepreneurship education; human capital; social capital; entrepreneurial learning; entrepreneurial self-efficacy; networks; mentors; design thinking, lean start-up approach; Australia 


\section{Introduction}

Given the rapid increase in start-ups and venture capital in recent times, there has been an emergence of new entities in entrepreneurial ecosystems that try to offer services to help budding and new entrepreneurs (Miller and Bound 2011). One of these entities is the start-up accelerator, also referred to as a start-up factory (Miller and Bound 2011) or seed accelerator (Hochberg 2016), which is an organization that delivers entrepreneurial education programmes and other start-up support and networking services to help entrepreneurs rapidly learn the lessons and avoid mistakes of managing and growing start-ups, especially in the early stages of venture development. However, while start-up accelerators have received much attention, they have received little research scrutiny (Hathaway 2016). Furthermore, they are often misunderstood or mistakenly grouped with other entities that work with early stage ventures (e.g. incubators, angels, and early stage venture capitalists). Yet, unlike incubators and providers of formal entrepreneurship education courses, start-up accelerators do not just focus on providing entrepreneurship education or low-cost infrastructure. They also aim to accelerate enterprises by integrating nascent entrepreneurs and start-ups into a network or ecosystem.

Building on rapid growth of start-up accelerators in the USA like Y Combinator and AngelPad which helped accelerate the growth of companies like AirBnB, Dropbox, Postmates and Vungle, other countries in the world have quickly adopted the accelerator model (Sepulveda 2012; Stross 2013). In the Asia Pacific region, Australia was an early adopter of the start-up accelerator model with the Melbourne Accelerator Programme that started in 2010. By 2017, there were about 30 start-up accelerators across different states, with a number starting overseas branches in cities around the Asia Pacific region (Bliemel et al. 2016). Recognizing the need for SME and start-up development, in the 2012 APEC Leaders' Declaration, APEC leaders endorsed the APEC Start-up 
Accelerator (ASA) initiative which facilitates member countries to establish platforms for building capacities for start-ups and young entrepreneurs (Shen 2014). Since then, as part of the ASA initiative, APEC member states have been active in hosting various start-up activities, like Chinese Taipei (APEC Start-up Accelerator Leadership Summit), Indonesia (Seminar on the Dynamics of SME), Malaysia (Global Entrepreneurship Summit), Peru (Start-up APEC Conference II), Russia (Young Entrepreneurship Network) and Korea (APEC Start-up Conference) (Shen 2014).

In the Asia Pacific, start-up accelerators have been especially helpful in complementing other entrepreneurship education and development initiatives. For example, Malaysia launched its Higher Education Institute Entrepreneurship Foundation (HEIEF) in 2010 to create high-quality talent with the intellectual attributes and entrepreneurship values required to achieve its New Economy Model by 2020 (MOHE 2010). Although start-up accelerators only began supplementing other entrepreneurship education programmes and incubator facilities from about 2012 onwards, this has helped contribute to university graduates engaging directly with entrepreneurial activities with 1114 graduates in 2011 growing to 1273 in 2012 and accelerating to 2387 in 2013, and 4060 in 2014 (Othman and Nasrudin 2016). Similarly, it is estimated that the number of students exposed to entrepreneurship knowledge and skills development through structured programmes had increased by 30 per cent in 2014 (Norfadhilah 2014). Thus, start-up accelerators are vital in supporting entrepreneurship for economic growth, which is particularly important to sustain the economic sustainability of the Asia Pacific region.

The rapid proliferation of start-up accelerators has also meant that they are viewed by other industries as organizations to learn from. In particular, accelerators have been seen as a means for some industries that are seeking to transform themselves, 
for example, the manufacturing sector in their efforts to transition to servitization by innovating capabilities and processes to shift from selling products to selling integrated products and services that deliver value in use. In this way, industries are transformed to be more service-oriented in order to capture more value from the value chain (Baines et al. 2009; Lightfoot, Baines, and Smart 2013). The emphasis of servitization is on leveraging on the knowledge or intellectual capital among manufacturers which forms the basis of significant potential value. It is also to develop innovative business models, enabling companies to move up the value chain and exploit higher value business activities (Roos, Bainbridge, and Jacobsen 2001; Roos, Pike, and Fernstrom 2005). Setting up their service divisions as spin-offs based on models of start-up accelerators has enabled many manufacturing firms to rapidly transform into servitization (Roos 2012, 2015), which is important in the increasingly competitive market.

Since the 1990s, organizations that deliver entrepreneurship education have grown in number, size and scope in Australia (Daly 2013) and also globally. Many of these programmes use a variety of pedagogical techniques to teach participating entrepreneurs a broad spectrum of content (Maritz and Brown 2013) despite little evidence on the efficacy of these programmes (Kuratko 2005; Rae 2012). The result is that such programmes may confuse potential entrepreneurs and negatively affect the overall impact of entrepreneurship education (Pittaway and Cope 2007). Consequently, the majority of the organizations offering these programmes may do nothing to enhance entrepreneurship skills and motivation (O'Connor 2013). Furthermore, there is a lack of consensus as to what, if any, course or training components are most effective in providing for entrepreneurial learning, in this emerging field (Alberti, Sciascia, and Poli 2004; Solomon, Duffy, and Tarabishy 2002). Furthermore, most entrepreneurship education courses tend to educate 'about' entrepreneurship rather than educating 'for' 
entrepreneurship (Kirby 2004). Therefore, our research is intended to contribute to a better understanding of entrepreneurship education in the context of start-up accelerators in terms of what should be taught and how it can be better delivered (Alberti, Sciascia, and Poli 2004; Gibb and Cotton 1998; Matlay 2009; Pittaway and Cope 2007; Bygrave 1993).

It is the ability to combine the learning components from a properly delivered entrepreneurship education programme with appropriate mentoring and relevant industry connections that purportedly help these start-up accelerators not only incubate new entrepreneurs but actually accelerate their development. In so doing, start-up accelerators attempt to combine the three components of entrepreneurial learning that Gibb (1993, 1997) has labelled'know-what', 'know-how'and'know-who'.'Knowwhat'and'know-how'can be understood in terms of developing knowledge and experience, important aspects of human capital. 'Know-who' can be understood in terms of developing ties or networks, which is an aspect of social capital. Research on the relationship between management and organizational performance has found that effective practices centre around the ability to integrate development of human capital (skills, experience and knowledge of employees) (Lepak and Snell 1999) with that of social capital (knowledge that exists in groups and networks) (Sung-Choon, Morris, and Snell 2007).

Therefore, the objective of this study is to examine the nature of entrepreneurial learning in terms of the extent to which they develop human capital ('know-what' and 'know-how') and social capital ('know-who') in start-up accelerators that offer a unique entrepreneurship learning experience that combines formal entrepreneurship education with other components like mentoring. The research contributes to previous literature by exploring two major dimensions of the 'black box': (1) how human capital is 
developed, by examining what content is taught and what processes are used in the entrepreneurship education component of start-up accelerators, and (2) if and how social capital adds value to the process of entrepreneurial learning. This is especially relevant in the Asia-Pacific context in response to calls for more research into these aspects (Redding and Rowley 2017) whereby both human capital and social capital play important roles in the business systems by working together to achieve something greater than the sum of the individual components (Redding and Rowley 2017). Thus, while much of the research examining human capital and social capital in entrepreneurship education in the Asia Pacific region is limited by the use of student samples (Sun et al. 2017), this research contributes to entrepreneurial learning theory by providing evidence that social capital or 'know-who' is just as important as the human capital development aspects of 'know-what' and 'know-how'. This is because 'knowwho' can provide nascent entrepreneurs with the means to better access 'know-what' and 'know-how' (Gibb 1997) to accelerate growth in their start-up ventures.

We find that although the emphasis of the programme was on the human capital aspects of 'know-what' (e.g. rapid prototyping) and 'know-how' (e.g. how to develop a business model), the participants found that the 'know-who' or social capital component was most significant in their learning. Furthermore, our results show that 'know-what', 'know-how' and 'know-who' are interrelated - by knowing 'who', participants learnt 'what' and 'how to'. In particular, mentors and experts were able to help improve entrepreneurial learning by integrating classroom-based content with real-world connections and networks. 


\section{Literature Review}

\section{Start-up Accelerators and Entrepreneurship Education}

Start-up accelerators offer limited duration (about three months on average) cohortbased programmes that incorporate entrepreneurship education programmes and mentorship which conclude with a 'demo day' where the entrepreneurs pitch to groups of qualified investors or the public (Hochberg 2016). While they are similar to traditional business incubators, their fixed duration nature combined with intensive entrepreneurship education programmes and mentorship is claimed to develop ventures that survive better outside of an incubator environment (Cohen 2013). Table 1 below summarizes the difference between start-up accelerators and incubators (Cohen 2013).

\section{Insert Table 1 about here}

Much of the formal knowledge and expertise in start-up accelerators is delivered through structured entrepreneurship education programmes by mainly experienced entrepreneurs to the members of the accelerators (Fishback et al. 2007; RadojevichKelley and Hoffman 2012). Fayolle, Gailly, and Lassas-Clerc (2006, 702) defined entrepreneurship education programmes as 'any pedagogical program or process of education for entrepreneurial attitudes and skills, which involves developing personal qualities'. However, following the lessons of the bursting of the dot-com bubble in the early 2000s, which were reinforced in the Global Financial Crisis in 2007, there was a realization of a need to move beyond pedagogy to include more mentoring and guidance for nascent ventures, with the intention of reducing high failure rates (O’Connell 2011).

Start-up accelerators adopted this approach whereby 'their primary goal is to increase the quantity and quality of entrepreneurs, influence entrepreneurial behaviour, 
entrepreneurial tendency and entrepreneurial outcomes' (Matlay 2009, 382). Besides formal mentoring, start-up accelerators also offer many (planned and unplanned) networking opportunities for participants, including with peers and mentors, who might be successful entrepreneurs, graduates of the accelerator, early stage investors or even corporate executives (Cohen 2013; Miller and Bound 2011). Start-up accelerators aim to increase both the quantity and quality of entrepreneurs in the ecosystem by attracting and motivating potential entrepreneurs and by influencing their behaviour (what they do and how they do it) through the development of both human capital and social capital.

However, Maritz and Brown (2013) and Cohen (2013) lament that despite the proliferation of start-up accelerators and entrepreneurship education providers, little is known about what is actually learnt in these programmes and how effective the teaching or delivery of these initiatives are. They call for research into the 'illumination of the black box of entrepreneurship education programs' and a better understanding of the interrelated parts of learning on these programmes and the relationships between them. This gap is not new: more than a decade previously, Gibb and Cotton (1998) argued that there was considerable conceptual confusion regarding what entrepreneurship education is e.g. what it does and should teach, how it should teach it and what it aims to and accomplishes. Little has explored on this aspect since the early study by Gibb and Cotton (1998), particularly in the context of start-up accelerators the Asia Pacific region.

\section{Human Capital and the Development of 'Know-What' and 'Know-How'}

Human capital theory suggests that organizations with more human capital (i.e. the combination of knowledge, skills and abilities of human resources) will generally secure superior outcomes (Becker 1964; Hatch and Dyer 2004), especially when the organization's focus is on innovation (Felício, Couto, and Caiado 2014). In the context 
of highly knowledge-intensive and competitive industries, it has been argued that these human capital elements are especially significant for start-ups and smaller firms as they provide the overall intellectual capital that enable them to sustain their competitive advantage (Youndt, Subramaniam, and Snell 2004). However, how human capital contributes to the process of innovation has eluded most researchers (Marvel and Lumpkin 2007) with a lack of research especially in understanding this phenomenon among new ventures (Freel 2005).

Two key characteristics, knowledge and experience, underpin human capital theory (Becker 1964). Cater and Cater (2009) found that human capital was a factor that explained performance differences in firms in general but most studies have found that this was especially more pronounced among smaller and newer firms. Shrader and Siegel (2007)'s longitudinal study of high-technology ventures found that for small, technology-based new ventures, human capital in the form of the quality of employees was the most important determinant for success because employees with more human capital (i.e. more education and experience) help firms implement new technologies more effectively (Wright et al. 2007). In terms of innovation, many researchers argue that human capital may play an even larger role in the future because of the rapidly increasing knowledge-intensive activities (Bosma et al. 2004; Tharenou and Seet 2014; Corral de Zubielqui et al. 2015; Jones and Corral de Zubielqui 2017; Honig 2001).

In a comprehensive meta-analysis of research spanning three decades on the relationship between human capital and entrepreneurial success, Unger et al. (2011) find a significant but small relationship between human capital and success, especially among smaller and younger firms. In particular, they found that the relationship was higher for knowledge/skills as compared to experience and suggest that there seems to be a bias in existing research which focuses mainly on the management competencies 
and experience of the lead entrepreneur (Zacharakis and Dale Meyer 2000). They also pointed to the need to move away from the individual level of understanding the relationship of human capital to outcomes, and to shift research on human capital away from a static view of entrepreneurship to a process view. In terms of skills, there is a need to 'explicate the processes that lead to acquisition of knowledge and skills' (Unger et al. 2011, 353). Some researchers have begun responding to this, for example, in the understanding of the effect of entrepreneurship education on innovation and other outcomes (Martin, McNally, and Kay 2013). Our research responds to that call by moving beyond merely content learning to understanding how some of the newer delivery techniques will help in the human capital development process of participants in start-up accelerators.

'Know-what' and 'know-how' as important aspects of entrepreneurial learning capture the human capital development component of what knowledge participants actually learn or receive from entrepreneurship education. However, unlike formal education, there is little uniformity in entrepreneurship education offerings; this is commonly considered to be related to the fact that entrepreneurship is an emerging field (Alberti, Sciascia, and Poli 2004; Solomon, Duffy, and Tarabishy 2002). It is recognized that most entrepreneurship education courses educate 'about' entrepreneurship rather than educating 'for' entrepreneurship (Kirby 2004). Only rarely do they focus on developing the skills, attributes and behaviour of the successful entrepreneur (Alberti, Sciascia, and Poli 2004). While they have the roots mainly in North America and Europe, these approaches are also generalizable to the Asia Pacific context as they share a 'common quest' of creating entrepreneurs (Kelley and Thomas 2011). In light of this, the study takes the definition offered by (Alberti, Sciascia, and Poli 2004,7$)$ that content learning is 'any form of knowledge or education offered by 
the program pertaining to both "about" and "for" entrepreneurship, that is the teaching of theory, history, skills, attributes and behaviour'.

The content of formal entrepreneurship education can be divided into two forms: traditional and contemporary. Traditional methods generally refer to a more analytical and prescriptive approach to entrepreneurship whereas contemporary methods refer to a more design and experientially based approach (Nielsen and Pia 2015; Osterwalder 2004). Table 2 summarizes the traditional components of 'know-what' and 'know-how' in entrepreneurship education. We briefly outline these traditional components entrepreneurial self-efficacy (ESE), skills and finance - below.

Insert Table 2 about here

Self-efficacy refers to 'people's beliefs about their capabilities to exercise control over their own activities and over events that affect their lives' (Bandura 1991, 257). One focus of many providers of entrepreneurship education traditionally has been to try to change the beliefs and attitudes of the entrepreneurs towards such behaviour and finally developing their self-efficacy or belief that they could do or master the behaviour that they were required to do (Bandura 1991; Fayolle and Gailly 2008; Rae 2012). Entrepreneurship educators have also traditionally focused on the development of entrepreneurial skills within the framework of a business plan (Hills 1988; Honig 2004). These skills relate to selling, marketing, developing a customer base, developing a product and areas of business law such as intellectual property and confidentiality (Bygrave 1993; Kuratko 2004; Kuratko 2005; Rae 2012; Ronstadt, Vesper, and McMullan 1988). Among these skills, traditional programmes teach entrepreneurs about entrepreneurial finance, and the need to access financing for ventures (Cohen and 
Levinthal 1990; Shepherd and Zacharakis 2001; Ronstadt, Vesper, and McMullan 1988).

There have been many limitations discussed in relation to traditional methods of entrepreneurship education including: their inability to enable and prepare the entrepreneur for the speed of change, dynamism, non-sequential nature, unpredictability, complexity and level of technological influence within the entrepreneurial landscape (Neck and Greene 2011). Indeed, traditional methods have not been satisfactory in preparing or providing the entrepreneur with the required skills, behaviours, attitudes and tools to survive in this environment (Fritscher and Pigneur 2009). Neck and Greene (2011) claim that traditional approaches to entrepreneurship education are based on a world of yesterday, a world where precedent was the foundation for future action and where history often did predict the future. Although the core of entrepreneurship is the identification and exploitation of opportunities (Shane and Venkataraman 2000), the majority of providers of entrepreneurship education adopt a more traditional approach and assume the opportunity has already been identified.

\section{'Know-What' and 'Know-How': Contemporary Perspectives}

In response to these issues, contemporary methods of entrepreneurship education have been developed that purportedly allow the entrepreneur to be more dynamic in the development of a venture, with the methods enabling increased pivoting, whereby entrepreneurs change directions but stay grounded in what they’ve learned (Ries 2011) and adapt in the creation phase to make the most of opportunities as they arise and to respond to barriers as they eventuate (Eisenmann, Ries, and Dillard 2012). Contemporary methods have also been developed in order to encompass a greater use of technology and experiential processes to reflect the unpredictable nature of entrepreneurship, equipping and educating the entrepreneur for their industry conditions 
(Pittaway 2004).

The majority of this new content has typically been centred on Design Thinking (DT), the Business Model Canvas (BMC) and the Lean Start-up Approach (LSA). Table 3 illustrates as the types of contemporary content and the predominant authors who are central to the debate on the merit in providing valuable entrepreneurial learning for entrepreneurs undergoing entrepreneurship education.

Insert Table 3 about here

DT in entrepreneurship focuses on the reconstruction and solution of problems rather than analysis of the problems (Johansson and Woodilla 2009). DT allows entrepreneurs to exploit opportunities in uncertain environments (Neck and Greene 2011). Building on DT and the lack of consensus within the field as to the legitimacy and benefit of business planning especially after the bursting of the dot-com bubble and the Global Financial Crisis, Osterwalder (2012) developed a more modern approach to business planning in the form of Business Model Ontology. In essence, its development and that of the $\mathrm{BMC}$ is an attempt to address the problem that the business planning process is an attractive and powerful learning process, but that a disproportionate amount of time is spent honing secondary research skills rather than actually taking smart action in the real world.

The LSA is very closely related to DT and the BMC and they are usually deployed in unison. The LSA is a hypothesis-driven approach to evaluating entrepreneurial opportunity. Entrepreneurs translate their vision into falsifiable business model hypotheses, then test the hypotheses using a series of 'minimum viable products', 
each of which represents the smallest set of features/activities needed to rigorously validate a concept (Eisenmann, Ries, and Dillard 2012). Validation is therefore also a key component of the LSA, where the participants develop a minimal viable product and then validate its worth and the various assumptions regarding it. Based on the validation feedback, entrepreneurs must then decide whether to persevere with their business model; 'pivot' by changing some model elements, or abandon the start-up. Figure 1 depicts the relationship between DT, the LSA and the BMC.

\section{Insert Figure 1 about here}

Analytical thinking is largely different to DT and is the basis for traditional forms of entrepreneurship education. This is reflected by Brown (2005) who describes that traditionally entrepreneurs are trained to think analytically (like social and natural scientists), suggesting that analytical thinking is good for analysis, cutting things apart and extrapolating and predicting from the past into the future, which is appropriate for approaches such as business planning (Fiet 2001a; Honig 2004). However, Brown (2005) suggests that it is not very good for trying to envision a new future and figuring out a way to change it. He proposes that DT is rooted in optimism, and the goal to get something done and to bring it to the marketplace. However, as illustrated by Figure 1 there is an overlap of analytical thinking and design thinking. The LSA and BMC predominantly are based on DT, but also have relationship to analytical thinking. This is evident when comparing the traditional business plan and contemporary BMC; there are inherent similarities and also differences between the two due to one being primarily analytical and the other being primarily design oriented.

However, despite the fact that Design Thinking, the Business Model Canvas and 
Lean Start-up Approach are becoming increasingly prevalent within entrepreneurship education offerings (Blank 2013; Eisenmann, Ries, and Dillard 2012; Neck and Greene 2011; Osterwalder 2004, 2012), there is very little empirical research investigating their actual value and benefits vis-à-vis traditional content. Therefore, a gap exists in the research to explore the benefit of these contemporary perspectives of 'know-what' and 'know-how' in enhancing entrepreneurial learning, which is what this research aims to address.

\section{Social Capital and the Development of 'Know-Who': The Missing Catalyst}

The newer, more contemporary approaches to delivering entrepreneurial learning also move beyond content or traditional human capital development to include networking and other aspects of social capital development (Bridge 2014). An important part of the Lean Start-up Approach is for entrepreneurs to get direct feedback from potential customers or key informants in the value chain, as opposed to traditional means of desktop research or market research surveys. Part of this comes from using networks to 'co-create' new products or services (Zijdemans and Tanev 2014).

Rae (2012) suggests that entrepreneurs who learn how to validate assumptions by reaching out to wider network and gaining feedback from key stakeholders in order to validate the hypothesis and assumptions (e.g. what customers are interested in and prepared to pay for production such as costs and availability and venture management) are relatively more successful in getting started as these assumptions were often found to be over-optimistic and had to be revised.

In entrepreneurship research, the term 'network' generally describes a mix of informal and formal relationships. This includes people and organizations that are linked through formal and social interactions (Kiss and Danis 2008) whereby formal relationships are often underpinned by informal, inter-personal relationships among 
members of different organizations (Perkmann and Walsh 2007). In the entrepreneurial context, networks allow start-ups to access and utilize external resources to overcome resource constraints so as to better facilitate survival and growth (Madhok 2002; BarNir and Smith 2002), and thereby minimizing some disadvantages of their 'smallness' and 'newness' (Aldrich and Auster 1986; BarNir and Smith 2002). Because of technological developments like the Internet, early stage ventures are increasingly relying on relationships rather than 'arms-length' in transactional market links (Chesbrough 2003; Cooke, Heidenreich, and Braczyk 2004; Seely-Brown and Duguid 2001).

Among entrepreneurs, networks and contacts with other people are social sources of opportunity-relevant information which can then be acted on by the ownermanager (Ozgen and Baron 2007). Social networks have been found to be important in opportunity recognition (Singh 2000) and the larger the entrepreneur's or ownermanager's social networks, the more opportunities they recognize (Dufays and Huybrechts 2014; Singh et al. 1999; Stam, Arzlanian, and Elfring 2014; Greve and Salaff 2003). This is especially relevant in highly communitarian societies in the Asia Pacific region (Ahmad and Seet 2009; Zhao and Lu 2016; Seet 2007).

In spite of the recognition that social capital is an important component in entrepreneurship (Gedajlovic et al. 2013), much of the research in entrepreneurship education has focused on human capital e.g. Business Model Canvas (Breuer 2013) or team learning (Harms 2015). Hence, there is a gap in terms of a deeper understanding of the roles of social capital like mentoring, which this research attempts to contribute to in the context of start-up accelerators.

\section{Research Method}

The exploratory nature of the study led to a qualitative research design to 'illuminate the black box' of entrepreneurship education by specifically examining in detail the human 
capital and social capital aspects of entrepreneurial learning within a start-up accelerator that uses contemporary Design Thinking methods. The study used in-depth semistructured interviews to explore the perceptions and experiences of start-up accelerator participants. The use of in-depth interviews enables a more nuanced exploration of a complex matter (Rubin and Rubin 2011). The opportunity for participants to engage in a discussion with the researcher, and for the researcher to probe responses mean that issues can be explored in detail. It also allows for richer understanding of the delivery of entrepreneurial learning content and this method of data collection is supported by other studies in the field which have used the same collection technique (Sullivan 2000; Man and Lau 2005).

Access to learning blogs that the participants were encouraged to complete was also provided. The purpose of these blogs was to allow the participants to discuss and self-reflect upon what they had learnt in the programme. This provided an additional source of data that facilitated triangulation.

\section{Sample}

The sample comprised participants of a start-up accelerator run by a South Australian university that involved both student entrepreneurs and new entrepreneurs from the surrounding council areas. Driven by manufacturing, South Australia - a state in Australia - experienced significant population and economic growth above the national average after the Second World War till the 1970s. However, since then, with the movement of manufacturing offshore (Beer 1998), the shift of 'head office' activity to Melbourne and Sydney (O'Connor and Stimson 1995), the collapse of the South Australian State Bank in the 1990s (Walmsley and Weinand 1997) and the severe nationwide drought in the 2000s negatively impacting on the driest state in the driest 
continent (Rutherfurd and Finlayson 2011), and most recently, the closure of manufacturing facilities in the automotive sector (e.g. Mitsubishi and Holden) as well as production/distribution facilities in the retail sector (e.g. Coca Cola), have negatively impact the South Australian economy (Clibborn, Lansbury, and Wright 2016). In 2014, South Australia began focusing on building an entrepreneurial ecosystem as part of its industrial transformation strategy (O’Connor and Reed 2015). Exploratory research mapping the South Australian entrepreneurial ecosystem shows a significant increase in networking and start-up events, co-working spaces, incubators and accelerators (Bliemel et al. 2016). The vibrancy of the entrepreneurial ecosystem in Adelaide, besides creating local impact, has had wider network effects and has led to the assistance of development of accelerators in the Asia Pacific region (e.g. ThincLab Singapore; Lindsay 2012).

Theoretical sampling was used as the goal was not to generalize to the wider population but to theory. The sample was designed to achieve a balance between those who had no experience (students) and those that had some experience (new entrepreneurs). In total, 20 semi-structured interviews of participants were conducted. The interview questions covered the following aspects:

- expectations of entrepreneurs prior to the programme,

- $\quad$ questions relating to what and how they learnt during the programme, and - $\quad$ questions pertaining to the expectations of the participant being met.

In terms of the learning blogs, only four participants completed them and triangulation was only possible for the results of these four participants.

As can be seen in Table 4, out of the 20 participants interviewed, 14 had completed the programme and 6 were in the final stages of the programme. The sample comprised more males (15 vs. 5 females), which is common in most start-up 
accelerators and formal entrepreneurship education programmes. For a universitysupported start-up accelerator, there was a relatively low number of students in the sample, with there being 15 non-students and 5 students. This is in contrast to the mainstream entrepreneurship education programmes or courses that are run in universities for their students which are made up entirely of university students. This is also in line with the practice that start-up accelerators need to be open to all but at the same time be competitive in terms of entry (Hochberg 2016). Hence, in the selection criteria, applicants, including students, were asked for their motivations for joining the start-up accelerator, with one of the sub-criteria being whether they were planning to start/grow their own ventures. The sample obtained from the start-up accelerator may be more appropriate and reflective of the real world of entrepreneurship whereby the majority of entrepreneurs are not just going to be students from university but people of all different ages from all different avenues of life. The majority of the entrepreneurs were also new entrepreneurs; this was deliberate as the programme chosen was created for nascent or beginner entrepreneurs.

Insert Table 4 about here

\section{Analysis}

Interviews were transcribed and checked for accuracy. As much as possible, interviews were written to a pre-determined structure covering a consistent range of issues to allow easier analysis across interviews. Individual transcripts were initially analysed with themes or patterns coded. Thereafter, these were combined across the entire interview data and overarching themes identified. Coding occurred inductively (Saldana 2009) in order to draw out the main themes and patterns. The findings from the interviews are 
presented under three headings:

- Know-what: Business Model Canvas;

- Know-how: Lean Start-up Approach; and

- Know-who: Mentors, Experts, Peers, Potential Customers and Key Stakeholders

\section{Discussion of results}

\section{Know-What: Business Model Canvas (BMC)}

As can be seen from Table 5, much of the content that the participants were looking for when entering the programme was provided by the BMC. As respondent E15 states, the BMC provided a structure and outline for the participants in regard to what they needed to do in order to create a business: 'I found that having something like the Business Model Canvas has given me a framework I can apply on a lot of things, I didn't have the knowledge of how to apply in that specific order or quite so simply.' For example, it taught the participants the need to develop revenue streams, discern partnerships and conduct customer validation.

Insert Table 5 about here

Participants found that the BMC was actionable and design oriented, enabling the participants to apply or test the various components of their business and adapt these components based on the feedback received. Respondent E18 said, 'For me, to be able to do, you know, countless canvasses, it constantly changes depending on who I speak to but it helps me to really understand what my concept [is] so much more, like 
thoroughly.' It appears to have made the business plan more adaptable to enable entrepreneurs to make the most of opportunities as they arise; it also appears to give a clearer picture of the necessary components of a venture.

Although the majority of the participants found the provision of the BMC to be beneficial, some of the participants found its highly structured approach to be problematic (Table 5). This is evident from respondent E12, who states that 'I already had an idea, I had a business plan and a working prototype so I was further along the path and so the programme wasn't entirely geared towards where I was with my project, it was more geared towards somebody at an earlier stage with an idea.' This meant that the BMC may be less applicable to individuals who began the programme further along the entrepreneurial learning process or who had specific, perhaps highly complex areas of particular difficulty, like licensing for example. This may suggest that the BMC is aimed at and more applicable to entrepreneurs who were looking to start or who were at the very beginning of the business creation process, rather than entrepreneurs who already had a product, business or prototype made and functioning.

\section{Know How: Lean Start-Up Approach (LSA)}

Through the LSA, participants were first taught how to develop a minimal viable product and second, the need to engage with customers and key stakeholders.

As shown in Table 6, learning the need for, and how to develop, a minimal viable product (MVP) provided the entrepreneurs with the ability to more easily move forward and progress the development of their business idea.

Prior to the programme, many participants struggled with the issue of their ideas and proposed businesses being too big, restricting or crippling their development due to cost or complexity. This is reflected in the following quote from participant E8: ‘ ... 
What I had done before the start-up accelerator programme was built here, add here and expand it, the next thing, it's unworkable and unmanageable and more importantly not something that you or I could do tomorrow.' The LSA and MVP made the idea or venture actionable, and the participants could actually move forward with its development as they could test it through showing potential customers and stakeholders, and develop it based on this feedback.

Insert Table 6 about here

Responses also indicate that participants were looking for the programme to teach them how to validate whether or not their idea was a viable business proposition (Table 7). This is illustrated by respondent E13: 'It validated that it was a business idea and programme that would or could be successful, it validated for me that I could do it'. Participants also appeared to learn that they needed to and could validate the assumptions they held about their business before actually building the product, as illustrated by respondent E6: 'During the start-up accelerator programme I realised that I can actually test all my assumptions and test exactly what customers want before I actually build the product. That was the biggest thing that I took away from the programme.'

Insert Table 7 about here 


\section{Know-Who: Potential Customers and Key Stakeholders}

Despite the start-up accelerator focusing on delivering contemporary content, many of the participants highlighted the 'people' aspect of their learning experience, namely their mentors, the experts that were involved in the programme, and the interactions with potential customers and key stakeholders. Many of the participants expressed a feeling of working in isolation prior to the programme and described themselves as having a tendency to ruminate, be indecisive and inactive. The participants identified that their confidence increased during the programme and that they found themselves going to events and talking to people that they would not have done prior to the programme. We examine this theme in more detail below.

\section{Mentors}

Mentors were found to be one of the predominant and most beneficial learning outcomes of the programme as well as one of the main processes of learning. The startup accelerator introduced and connected the participants to mentors that they needed to know and work with, mentors that they would not have had access to, or known how to access outside of the programme.

The participants often described working with or learning from their mentors as the 'best' or 'most valuable' means of learning offered by the programme (Table 8). This value was predominantly derived from the real world experience of the mentors. Respondent E9 demonstrates this point: 'The mentors, having had been very successful in their own businesses have some ideas about what you can and can't do and they straighten you out.' The participants valued the opportunities to ask questions and receive advice based on the prior experience of their mentors. 
The second pattern to emerge was the guidance provided by, and the ability of, the mentors in steering participants in the right direction, developing their ESE and helping them to alter their entrepreneurial behaviour. According to respondent E18:'My mentor has led me to speak to different people which has led to bigger things and people and places and events that I would never have known about if it wasn't for her.' Similarly, respondent E9 states: 'Where the mentors come in really handy is they say, "Look, here is your idea, go see this printer because he will be able to help you with the printing," for instance; or "go see the Harvey World Travel guy because he will be interested in what you are doing.",

Learning through the mentors was also evident as the participants received advice, information, problem solving, feedback, emotional support and further connections to various individuals, groups and activities that they had not known about or had access to prior to the programme and their mentor relationship. This is in line with existing literature by Hegarty (2006) which identifies the advantages of mentorship coming from the knowledge which is derived from being able to ask questions and receive practical advice as well as seeing and hearing someone who has gone through an entrepreneurial process and experienced failures and successes.

Effective mentorship was found to be a key driver in regard to the development of ESE and entrepreneurial behaviour, with mentors being able to provide advice, motivation and emotional support for entrepreneurial risk taking and behaviour (St-Jean and Mathieu 2015; Hoang and Antoncic 2003; Ahsan et al. 2018). The mentors helped 
develop ESE and change entrepreneurial behaviour by motivating, encouraging and directing the participants, telling them 'to do this', 'go see this person, they may be able to help', 'or go see this person, they will be interested'.

\section{Experts}

The start-up accelerator introduced the participants to experts with the knowledge and expertise who could help the participants learn about and perform skills that they were lacking in. This included providing access to law and design students and experts in fields such as marketing, search engine optimization and production, that the participants did not have access to outside of the programme. Many of the participants found this to be one of the most valuable outcomes of the programme.

Prior to the programme, many of the participants stated that they did not know where to begin in looking for this kind of expertise (e.g. who to contact), let alone specifically what they needed to have done, as illustrated in Table 9. Respondent E3 highlights this point:

There is a lot of basic advice that I got that I didn't know, like starting a website, I didn't know how to do that. There is a lot of things involved that I didn't have or hadn't thought of, I didn't know how or where to start or who to look for. The advice I got on how to do it cheaper and better through getting contacts was all really, really good. I feel like I have contacts and know where to start looking.

Insert Table 9 about here

This aligns with existing research which find that an effective entrepreneurship education programme should introduce nascent entrepreneurs to people who might be 
able to facilitate their success, such as expert practitioners (Miles et al. 2017; St-Jean and Mathieu 2015). The participants expressed that this would be an invaluable learning outcome as similar to the mentors, they did not have access to, or know how to access these contacts. The participants were seeking to be connected to 'experts' (St-Jean et al. 2017) who could assist them with the development of a website or logo, the drafting a confidentiality statement, provide them with advice regarding intellectual property, search engine optimization, production, different manufacturing techniques and marketing.

Not only did the experts provide or teach these areas of expertise, they also, in line with research by (Hoang and Antoncic 2003), connected the participants to further networks of skilled individuals that could be of use to the participants and their ventures. The degree of importance and value the participants were discovered to place on these networks provides credence to Gibb (1997) and other research in the Asia Pacific context (Batjargal and Liu 2004; Zhao, Frese, and Giardini 2010) that success in entrepreneurship is dependent not only on knowledge but the network of individuals with whom the entrepreneur is connected.

Although the programme brought in some experts, there was still demand from the participants for the provision of further access to individuals with these particular areas of skill, knowledge and expertise. As shown by respondent E12:'I would have liked more intensive focus on certain things such as exposure to people who assist with registering a trade mark or how to write a contract ... If there had just been a person there who could have sat down and said this is what you need to do to write a privacy policy for your website.'

Peers

The third group of people identified that the participants wanted to be connected to and 
learn from, were the other participants (Kacperczyk 2013; Sosa 2011). The participants had wanted to work and learn more collaboratively with their fellow participants (Table 10). This is what Lévesque, Minniti, and Shepherd (2009, p 551) defined as collaborative learning, which is 'the process of learning through participation and cooperation with people. 'Where this varies from social learning is that it is participative, and not purely observational.

Insert Table 10 about here

We found that the participants wanted to learn collaboratively and that the use of this learning process would have been an area of significant improvement for the programme. The importance the participants attach to being able to work with other nascent entrepreneurs and learn from them reflects the literature by Pittaway and Cope (2007) who propose that collaborative learning between nascent entrepreneurs can significantly increase their learning and preparedness for the entrepreneurial environment. The reason for this as noted by Clements and Moore (2009), is that it helps participants deal with uncertainty and ambiguity and problems in a real world environment, creating more emotional exposure in the programme and hence preparing them for the entrepreneurial environment in which they will operate.

The lone entrepreneurs who were not working in teams in the start-up accelerator expressed the desire to be able to work collaboratively with other entrepreneurs and people. The reason for this is that they thought it would provide them with access to the insight and skills of other people that are different from their own and that it would increase their level of motivation and confidence (ESE), thus increasing the chances of a venture's creation and survival. This sentiment is reflected in the 
research by Blank (2013) which finds that entrepreneurial teams as opposed to lone entrepreneurs are more likely to successfully start and manage new ventures.

\section{Potential Customers and Key Stakeholders}

The participants also described the learning received from the customers and key stake- holders as practical knowledge and information specific to their individual business. Respondent E6 illustrates this point: 'Each week I had to talk to customers and so that was the process in which I learnt a lot about what they want and what I can do as a business. To learn more about the business idea, it is definitely talking to customers.' Participants received knowledge and information regarding what they could offer their customers, how much their customers would pay for their product or service, what their customers really wanted and needed, where changes needed to be made to their product or service and what did their customer understand and not understand about their business (Table 11). Prior to the programme, participants stated that they did not understand the need for or know how to engage with potential customers/ stakeholders, nor were they engaging with potential customers and stakeholders. This led to participants building their ventures on the basis of their own assumptions, instead of basing it on customer and stakeholder information. Participants stated that they had wasted time and, in some instances, money on ideas which, had they used ESE, could have been identified very quickly as having little value.

Participants referred to their idea or business before the programme as 'just being in their own head' - they made up their own assumptions about what was real and correct, what would work and what would not work. None of these preconceptions were based on customer or supplier feedback and interacting with potential customers and suppliers tested the assumptions the participants held about their business by providing them with new knowledge, as evidenced by respondent E12 in Table 11. 
The participants revealed a theme that learning to speak to their potential customers and stakeholders enabled them to learn and discern based on real data who their customers really might be, what their customers really wanted and needed and how they might provide value for their customers, with a number reflecting that engaging with potential customers and stakeholders will now be their first point of call for any future ideas.

\section{Summary: Enhancing 'Know-What' and 'Know-How'with 'Know-Who'}

A key finding from this study is that while the contemporary 'know-what' and 'knowhow' in the form of Design Thinking, the Business Model Canvas and Lean Start-up Approach is well received by start-up accelerator participants, it was the 'know-who' component that really enhanced their entrepreneurial learning experiences. To that end, this study reinforces earlier research that found enhanced learning coming from the knowledge which comes from seeing and hearing from someone who has gone through an entrepreneurial process and experienced failures and success, and the opportunity to ask questions and receive practical advice (Hegarty 2006). It also reinforces the importance of social capital (Gedajlovic et al. 2013) that can act as a key driver or catalyst in regard to bridging learning to the development of ESE and entrepreneurial behaviour (Hoang and Antoncic 2003).

From the study, it can be seen that it is 'know-who' that closes the learning loop with 'know-what' and 'know-how' for entrepreneurs (Argyris 2002; Hampden-Turner 1993). The learning of 'know-who' has a positive impact on the development of 'knowhow' through social learning theory which advances that learning occurs when an 
individual is motivated to perform by observing experienced people and imitating them (Bandura 1977). For example, the interactions with experts allow the start-up accelerator participants to learn about the practice of entrepreneurship and the advice and information from them, plus their successful or failed entrepreneurial experiences help start-up accelerator participants to have a better understanding of what needs to be done or avoided to develop their entrepreneurial ventures more successfully (i.e. 'knowhow') (Stokes, Wilson, and Wilson 2010). The mentors also help change entrepreneurial behaviour by motivating, encouraging and directing the participants. 'Know-who' also has a positive impact on the development of 'know-what'. In particular, it is through the interactions with potential customers and key informants in the value chain that allow participants to have key insights into what customers are really looking for and this will allow them to change their product or business model quickly instead of investing too much time and resources in unviable ideas (Eisenmann, Ries, and Dillard 2012). Put together, social capital through 'know-who' enhances the human capital of 'know-what' and 'know-how' by developing the capacity of participants to problem solve, motivate themselves and develop a higher level of entrepreneurial self-efficacy and emotional support for entrepreneurial risk taking and behaviour. This is also applicable in the Asia Pacific context with relationships and networks being perceived as critical in facilitating entrepreneurship and creating value (Zhao, Frese, and Giardini 2010).

\section{Limitations and Future Research}

Our study has two noticeable limitations. First, it is based on a relatively small sample of start-up accelerator participants and as such, this research does not aim to produce results that are universally applicable. Further, it does not cover other stakeholders as part of the start-up accelerator (for example, the directors, mentors, instructors, and 
experts) as the focus was on understanding what and how the participants in the start-up accelerator learnt from their own perspectives and accounts. Future research should examine the phenomenon among larger samples of different types of start-up accelerator participants and stakeholders.

Second, the process of learning is an ongoing one which may have different outcomes at different stages of the entrepreneurial journey. The interviews and blogs only captured a moment in time, albeit with retrospective bias. Also, any learning that actually took place would be based on the subjective opinion and perception of the participants. That is, do they think or feel that they learnt something, how do they think or feel that they learnt it and what do they think they have learnt. We did not examine the tangible or quantifiable measure of this learning. While the research found that the amount of benefit and development the participants perceive themselves to have gained from learning and completing the programme in the start-up accelerator was positive, whether or not the contemporary approaches to entrepreneurship education in the startup accelerator will ultimately lead to increased entrepreneurial success is unknown. To really see how the participants put their 'know-what', 'know-how' and 'know-who' into practice, further ongoing contact will be needed and future research would benefit from longitudinal studies.

\section{Conclusion}

The study's objective was to examine the extent and nature of entrepreneurial learning in terms of the extent to which they develop human capital ('know-what' and 'knowhow') and social capital ('know-who') in start-up accelerators.

Overall, the study shows that the processes of 'know-what', 'know-how' and 'know-who' are interrelated - by knowing 'who', participants learnt 'what' and 'how 
to'. The research therefore makes the important contribution to entrepreneurial learning theory by shining a bit of light into 'the black box of entrepreneurship education' by providing evidence of that 'know-who' is just as important as 'know-what' and 'knowhow' as 'know-who' can actually provide entrepreneurs with the means to access 'know-what' and 'know-how'. The study also answers calls for more research on actual entrepreneurs as opposed to students undergoing entrepreneurship education courses in higher education institutions (Robinson, Huefner, and Keith Hunt 1991; Seet and Seet 2006).

Any form of entrepreneurial learning leading to developing ESE has been emphasized by various researchers on the basis that increasing desirable entrepreneurial behaviour would increase the likelihood of success, particularly in being able to identify, validate and take advantage of entrepreneurial opportunities (Chandler and Jansen 1997; Karlsson and Moberg 2013). The study contributes to entrepreneurial learning research and practice by showing that in the context of a start-up accelerator that is implementing contemporary entrepreneurial education methods (which incorporate ideas like the Business Model Canvas, the Lean Start-up Approach and mentoring), the combination of human capital and social capital is a powerful catalyst for developing Entrepreneurial Self-Efficacy. It therefore finds evidence that start-up accelerators, by closing the learning loop and using social learning techniques, are responding to earlier critiques of entrepreneurship education that note that effective entrepreneurial learning programmes must show students 'how' to behave entrepreneurially (Ronstadt 1987; St-Jean et al. 2017). In particular, it reinforces the issues raised by Rae (2012) and Fayolle and Gailly (2008) that programmes that developed ESE enable the participants to engage with potential stakeholders and acquire this kind of data instead of ruminating or being inactive, which may result in those 
participants' ventures being relatively more successful in getting started and surviving.

Up until the early 2000s, entrepreneurship education was largely confined to North America (Katz 2003). However, since then, given the success of early internet start-ups driven by the development of the Internet, entrepreneurship education programmes have grown rapidly in many parts of the world, and has experienced phenomenal expansion in the Asia Pacific (Kelley and Thomas 2011; Seet and Seet 2006; Norasmah and Norfadhilah 2016; Matlay 2016). Among the various innovations in entrepreneurship education, start-up accelerators were formed as a response to address the high attrition and other errors that emerged from the dot-com bubble and the Global Financial Crisis (Haines 2014a). As noted in the introduction, start-up accelerators have been multiplying in numbers across many Asia Pacific countries (Shen 2014). Just as the Lean Start-up Approach proposes pivoting towards a successful business model, the various Asia Pacific countries will iterate their models of start-up accelerators to adapt to local, culturally specific conditions (Haines 2014b; Solesvik, Westhead, and Matlay 2014), as they learn from mistakes among countries that have started early like Australia (Maritz, Jones, and Shwetzer 2015). For example, while the Techstars accelerator worked well in the USA and in the UK, the lack of supportive foreign visas and minimal ongoing government support stymied the growth of imitative models like ANZ Innovyz Start in Australia (Bliemel et al. 2016). In places like Singapore and Taiwan, strong government promotion and investment in start-up accelerators have seen many start-ups being put through these schemes but the limited size of domestic markets has led to many being unable to overcome the 'valley of death'(Moore 1999; Shen 2014). Regardless of this, research on what makes accelerators in Australia and other Asian countries successful has found significant similarities in that, in terms of supporting entrepreneurial ventures, venture success is 
highly contingent on them being able to leverage on the relationships or social capital that they have within the entrepreneurial ecosystem (Bliemel et al. 2016; Vanhonacker, Zweig, and Chung 2006; Shen 2014).

A recent study among New Zealand start-up accelerators show that start-up accelerators can be excellent platforms for authentic learning for nascent entrepreneurs (Miles et al. 2017) but the authors also noted that there was a need for context specific research to examine whether start-up accelerators also helped develop specific entrepreneurial competencies like the ability to develop, harness, and leverage human, organizational, social, and economic capital. This research attempts to contribute to better understanding that link. Time will tell but hopefully, if the phenomenon of startup accelerators continues to develop these techniques of growing both human and social capital in the Asia Pacific, there will be fewer entrepreneurial failures and more successful innovative ventures in the region in the future. Not only that, the ability to successfully do so will also spill-over onto other players in the service sector that are closely watching and experimenting e.g. manufacturing firms that are planning to rapidly servitize in order to capture more value higher up the value chain. 


\section{Disclosure statement}

No potential conflict of interest was reported by the authors.

\section{Notes on contributors}

$\mathrm{Pi}$-Shen Seet is a Professor of Entrepreneurship and Innovation in the Management discipline at Edith Cowan University's School of Business and Law where he is also the deputy director of the Centre for Work and Organizational Performance. He conducts research and supervises research students in entrepreneurship, innovation, family business, international business and human resource management.

Janice Jones is a senior lecturer at the Flinders Business School, Flinders University. Her research interests include human resource development and innovation, particularly in smaller enterprises, and corporatization of healthcare organizations.

Lloyd Oppelaar completed a bachelor's of Business (Honours) Degree at the Flinders Business School, Flinders University. He is currently marketing coordinator at Community Living Australia, an organization that provides personalized services and support to people with disabilities.

Graciela Corral de Zubielqui is a senior lecturer of the postgraduate Project Management and Innovation area in the Entrepreneurship, Commercialization and Innovation Centre, The University of Adelaide. Her research interests include innovation, knowledge transfer, collaboration activities between government, industry and university, SMEs performance and impact on regional economic development. 


\section{References}

Ajzen, Icek. 1991. "The Theory of Planned Behavior." Organizational Behavior and Human Decision Processes 50 (2): 179-211. doi:10.1016/0749-5978(91)90020-T. Ahmad, Noor Hazlina, and Pi-Shen Seet. 2009. "Understanding Business Success through the Lens of SME Founder-Owners in Australia and Malaysia." International Journal of Entrepreneurial Venturing 1 (1): 72-87.

Ahsan, Mujtaba, Congcong Zheng, Alex DeNoble, and Martina Musteen. 2018. "From Student to Entrepreneur: How Mentorships and Affect Influence Student Venture Launch.” Journal of Small Business Management 56 (1): 76-102. doi:10.1111/jsbm.12362.

Alberti, Fernando, Salvatore Sciascia, and Alberto Poli. 2004. "Entrepreneurship Education: Notes on an Ongoing Debate." Paper presented at the Proceedings of the 14th Annual IntEnt Conference, University of Napoli Federico II, Italy.

Aldrich, Howard, and Ellen R. Auster. 1986. "Even Dwarfs Started Small: Liabilities Ofage and Size and Their Strategic Implications." Research in Organizational Behavior 8: 165-186.

Argyris, Chris. 2002.“Double-Loop Learning, Teaching, and Research."Academy of Management Learning \& Education 1 (2): 206-218. doi:10.5465/AMLE.2002.8509400.

Baines, T. S., H. W. Lightfoot, O. Benedettini, and J. M. Kay. 2009. "The Servitization of Manufacturing: A Review of Literature and Reflection on Future Challenges." Journal of Manufacturing Technology Management 20 (5): 547-567. doi:10.1108/17410380910960984.

Bandura, Albert. 1977. Social Learning Theory. Englewood Cliffs, NJ:Prentice-Hall. Bandura, Albert. 1991."Social Cognitive Theory of Self-Regulation."Organizational Behavior and Human Decision Processes 50 (2): 248-287. doi:10.1016/07495978(91)90022-L.

BarNir, Anat, and Ken A. Smith. 2002. "Interfirm Alliances in the Small Business: The Role of Social Networks." Journal of Small Business Management 40 (3): 219232. doi:10.1111/1540-627X.00052.

Batjargal, Bat, and Mannie Liu. 2004."Entrepreneurs'Access to Private Equity in China: The Role of Social Capital.” Organization Science 15 (2): 159-172. doi:10.1287/orsc.1030.0044.

Becker, Gary S. 1964. Human Capital. Chicago, IL: Chicago University Press.

Beer, Andrew. 1998. "Immigration and Slow-Growth Economies: The Experience of South Australia and Tasmania.” Australian Geographer 29 (2): 223-240. doi:10.1080/00049189808703216.

Blank, Steve. 2013."Why the Lean Start-up Changes Everything." Harvard Business Review 91 (5): 63-72.

Bliemel, Martin J, Ricardo G. Flores, Saskia de Klerk, Morgan P. P. Miles, Bianca Costa, and Pedro Monteiro. 2016."The Role and Performance of Accelerators in the Australian Startup Ecosystem.” UNSW Business School Research Paper (2016MGMT03).

Bosma, Niels, Mirjam van Praag, Roy Thurik, and Gerrit de Wit. 2004. "The Value of Human and Social Capital Investments for the Business Performance of Startups." Small Business Economics 23 (3): 227-236.

Breuer, Henning. 2013. "Lean Venturing: Learning to Create New Business through Exploration, Elaboration, Evaluation, Experimentation, and Evolution." International Journal of Innovation Management 17 (3): 1340013. doi:10.1142/s1363919613400136. 
Bridge, Simon. 2014. "Exploring the Nature of Social Capital to Facilitate Its Inclusion in Enterprise Education." Education + Training 56 (8/9): 839-851. doi:10.1108/ET04-2014-0043.

Brown, T. 2005. "Strategy by Design." Fast Company 95: 52-54.

Bygrave, William D. 1993. "Theory Building in the Entrepreneurship Paradigm."

Journal of Business Venturing 8 (3): 255-280. doi:10.1016/0883-9026(93)90031-Y.

Bygrave, William D. 1997. The Portable MBA in Entrepreneurship. 2nd ed. The

Portable MBA Series. New York: J. Wiley \& Sons.

Cater, Toma, and Barbara Cater. 2009. "(in)Tangible Resources as Antecedents of a

Company's Competitive Advantage and Performance." Journal for East European

Management Studies 14 (2): 186-209.

Chandler, Gaylen N., and Erik Jansen. 1997. "Founder Self-Efficacy and

Venture Performance: A Longitudinal Study." Academy of Management

Proceedings 1997 (1): 98-102. doi:10.5465/ ambpp.1997.4980945.

Chesbrough, H. W.2003. Open Innovation: The New Imperative for Creating and

Profiting from Technology. Cambridge, MA: Harvard Business School Press.

Clements, B. and S. Moore 2009. SPEED Final Report by the LEAD Institution.

Wolverhampton: Institute for Innovation and Enterprise, The University of

Wolverhampton.

Clibborn, Stephen, Russell D. Lansbury, and Chris F. Wright. 2016."Who Killed the

Australian Automotive Industry: The Employers, Government or Trade Unions?"

Economic Papers: A Journal of Applied Economics and Policy 35 (1): 2-15. doi:10.1111/1759-3441.12127.

Cohen, Susan. 2013. "What Do Accelerators Do? Insights from Incubators and Angels." Innovations: Technology, Governance, Globalization 8 (3-4): 19-25.

Cohen, Wesley M., and Daniel A. Levinthal. 1990.“Absorptive Capacity: A New

Perspective on Learning and Innovation.” Administrative Science Quarterly 35 (1):

128-152. doi:10.2307/2393553.

Cooke, P., M. Heidenreich, and H. Braczyk. 2004. Regional Innovation Systems: The

Role of Governance in a Globalised World. London: Routledge.

Corral de Zubielqui, Graciela, Janice Jones, Pi-Shen Seet, and Noel Lindsay.

2015."Knowledge Transfer between Actors in the Innovation System: A Study of Higher Education Institutions (HEIS) and SMES." Journal of Business \& Industrial Marketing 30 (3/4): 436-458. doi:10.1108/JBIM-07-2013-0152.

Daly, P. 2013. Towards a City of Entrepreneurs: The Emergence of Adelaide as a Recognised Start-up Community. Adelaide City Council.

Dimov, Dimo P., and Dean A. Shepherd. 2005. "Human Capital Theory and Venture Capital Firms: Exploring 'Home Runs' and 'Strike Outs'.' Journal of Business Venturing 20 (1): 1-21. doi:10.1016/j. jbusvent.2003.12.007.

Dufays, Frédéric, and Benjamin Huybrechts. 2014. "Connecting the Dots for Social Value: A Review on Social Networks and Social Entrepreneurship." Journal of Social Entrepreneurship 5 (2): 214-237. doi:10.1080/19420676.2014.918052.

Eisenmann, Thomas R, Eric Ries, and Sarah Dillard. 2012. "Hypothesis-Driven Entrepreneurship: The Lean Startup." Harvard Business School Entrepreneurial Management Case No. 812-095.

Fayolle, Alain, and Benoit Gailly. 2008. "From Craft to Science: Teaching Models and Learning Processes in Entrepreneurship Education." Journal of European Industrial Training 32 (7): 569-593. doi:10.1108/03090590810899838. 
Fayolle, Alain, Benoît Gailly, and Narjisse Lassas-Clerc. 2006."Assessing the Impact of Entrepreneurship Education Programmes: A New Methodology.”Journal of European Industrial Training 30 (9): 701-720. doi:10.1108/03090590610715022.

Felício, J. Augusto, Eduardo Couto, and Jorge Caiado. 2014. "Human Capital, Social Capital and Organizational Performance."Management Decision 52 (2): 350-364. doi:10.1108/MD-04-2013-0260.

Fiet, James O. 2001a.“The Theoretical Side of Teaching Entrepreneurship."Journal of Business Venturing 16 (1): 1-24. doi:10.1016/S0883-9026(99)00041-5.

Fiet, James O. 2001b."The Pedagogical Side of Entrepreneurship Theory." Journal of Business Venturing 16 (2): 101-117. doi:10.1016/S0883-9026(99)00042-7.

Fishback, Bo, Christine Gulbranson, Robert Litan, Lesa Mitchell, and Marisa Porzig. 2007. 'Finding Business 'Idols': A New Model to Accelerate Start-Ups. Ewing Marion Kauffman Foundation."

C. Scott Dempwolf, Jennifer Auer and Michelle D'Ippolito (2014), Innovation Accelerators: Defining Characteristics Among Startup Assistance Organizations, SBA (Small Business Administration), Optimal Solutions Group, LLC.

Dinah Adkins (2011), What are the new seed or venture accelerators.

Freel, Mark S. 2005. "Patterns of Innovation and Skills in Small Firms." Technovation 25 (2): 123-134. doi:10.1016/S0166-4972(03)00082-8.

Fritscher, Boris, and Yves Pigneur. 2009."Supporting Business Model Modelling: A Compromise between Creativity and Constraints." Paper presented at the TAMODIA. Gedajlovic, Eric, Benson Honig, Curt B. Moore, G. Tyge Payne, and Mike Wright. 2013. "Social Capital and Entrepreneurship: A Schema and Research Agenda." Entrepreneurship Theory and Practice 37 (3): 455-478. doi:10.1111/etap.12042.

Gibb, Allan A. 1993. "Enterprise Culture and Education: Understanding Enterprise Education and Its Links with Small Business, Entrepreneurship and Wider Educational Goals." International Small Business Journal 11 (3): 11-34. doi:10.1177/026624269301100301

Gibb, Allan A. 1997. "Small Firms' Training and Competitiveness. Building upon the Small Business as a Learning Organisation." International Small Business Journal 15 (3): 13-29. doi:10.1177/0266242697153001.

Gibb, A. A., and J. Cotton. 1998. "Entrepreneurship in Schools and College Education-Creating the Leading Edge." Paper presented at the Background paper to the conference to be held at the Department of Trade and Industry Conference Centre.

Gorman, Gary, Dennis Hanlon, and Wayne King. 1997."Some Research Perspectives on Entrepreneurship Education, Enterprise Education and Education for Small Business Management: ATen-Year Literature Review." International Small Business Journal 15 (3): 56-77. doi:10.1177/0266242697153004.

Greve, Arent, and Janet W. Salaff. 2003."Social Networks and Entrepreneurship."Entrepreneurship Theory and Practice 28 (1): 1-22. doi:10.1111/1540-8520.00029.

Haines, Julia Katherine. 2014a. "Emerging Innovation: The Global Expansion of Seed Accelerators." Paper presented at the Proceedings of the companion publication of the 17th ACM conference on Computer supported cooperative work \& social computing.

Haines, Julia Katherine. 2014b. "Iterating an Innovation Model: Challenges and Opportunities in Adapting Accelerator Practices in Evolving Ecosystems."Paper presented at the Ethnographic Praxis in Industry Conference Proceedings. 
Hampden-Turner, C. 1993. "Dilemmas of Strategic Learning Loops.” In Strategic Thinking : Leadership and the Management of Change : Symposium : Revised Selected Papers, edited by John Hendry, Gerry Johnson and Julia Newton, 327-346. Chichester: Wiley.

Harms, Rainer. 2015. "Self-Regulated Learning, Team Learning and Project Performance in Entrepreneurship Education: Learning in a Lean Startup Environment." Technological Forecasting and Social Change 100 (Supplement C): 21-28. doi:10.1016/j.techfore.2015.02.007.

Hatch, Nile W., and Jeffrey H. Dyer. 2004. "Human Capital and Learning as a Source of Sustainable Competitive Advantage.” Strategic Management Journal 25 (12): 1155-1178. doi:10.1002/smj.421.

Hathaway, Ian. 2016."Accelerating Growth: Startup Accelerator Programs in the United States."Advanced Industry Series (81).

Hegarty, Cecilia. 2006. "It's Not an Exact Science: Teaching Entrepreneurship in Northern Ireland."

Education + Training 48 (5): 322-335. doi:10.1108/00400910610677036.

Hills, G. E. 1988. "Variations in University Entrepreneurship Education: An Empirical Study of an Evolving Field." Journal of Business Venturing 3: 109-122.

Hoang, Ha, and Bostjan Antoncic. 2003. "Network-Based Research in Entrepreneurship: A Critical Review." Journal of Business Venturing 18 (2): 165187. doi:10.1016/S0883-9026(02)00081-2.

Hochberg, Yael V. 2016. "Accelerating Entrepreneurs and Ecosystems: The Seed Accelerator Model." Innovation Policy and the Economy 16 (1): 25-51. doi:10.1086/684985.

Honig, Benson. 2001. "Human Capital and Structural Upheaval: A Study of Manufacturing Firms in the West Bank." Journal of Business Venturing 16 (6): 575594. doi:10.1016/S0883-9026(99)00060-9.

Honig, Benson. 2004. "Entrepreneurship Education: Toward a Model of Contingency-Based Business Planning." Academy of Management Learning \& Education 3 (3): 258-273. doi:10.5465/amle.2004.14242112.

Honig, Benson, and Tomas Karlsson. 2004."Institutional Forces and the Written Business Plan.” Journal of Management 30 (1): 29-48. doi:10.1016/j.jm.2002.11.002.

Jack, Sarah L., and Alistair R. Anderson. 1999."Entrepreneurship Education within the Enterprise Culture: Producing Reflective Practitioners."International Journal of Entrepreneurial Behavior \& Research 5 (3): 110-125. doi:10.1108/13552559910284074.

Johansson, Ulla, and Jill Woodilla. 2009. “Towards an Epistemological Merger of Design Thinking, Strategy and Innovation."Paper presented at the 8th European Academy of Design Conference.

Jones, Jane, and Graciela Corral de Zubielqui. 2017. “Doing Well by Doing Good: A Study of University-Industry Interactions, Innovationess and Firm Performance in Sustainability-Oriented Australian SMEs." Technological Forecasting and Social Change 123 (Supplement C): 262-270. doi:10.1016/j. techfore.2016.07.036.

Kacperczyk, Aleksandra J. 2013. "Social Influence and Entrepreneurship: The Effect of University Peers on Entrepreneurial Entry.” Organization Science 24 (3): 664-683. doi:10.1287/orsc.1120.0773.

Karlsson, Tomas, and Kåre Moberg. 2013. "Improving Perceived Entrepreneurial Abilities through Education: Exploratory Testing of an Entrepreneurial Self Efficacy 
Scale in a Pre-Post Setting." The International Journal of Management Education 11 (1): 1-11. doi:10.1016/j.ijme.2012.10.001.

Katz, Jerome A. 2003. "The Chronology and Intellectual Trajectory of American Entrepreneurship Education: 1876-1999.” Journal of Business Venturing 18 (2): 283-300. doi:10.1016/S0883-9026(02)00098-8.

Kelley, Donna, and Hugh Thomas. 2011. Entrepreneurship Education in Asia.

Cheltenham: Edward Elgar. Kirby, David A. 2004. "Entrepreneurship Education: Can Business Schools Meet the Challenge?" Education + Training 46 (8/9): 510 519. doi:10.1108/00400910410569632.

Kiss, Andreea N., and Wade M. Danis. 2008. "Country Institutional Context, Social Networks, and New Venture Internationalization Speed." European Management Journal 26 (6): 388-399. doi:10.1016/j. emj.2008.09.001.

Kuratko, Donald F. 2004. "Entrepreneurship Education in the 21st Century: From Legitimization to Leadership." In USASBE National Conference Proceedings 16: 4560 .

Kuratko, Donald F. 2005. "The Emergence of Entrepreneurship Education:

Development, Trends, and Challenges." Entrepreneurship: Theory \& Practice 29 (5): 577-597.

Lepak, David P., and Scott A. Snell. 1999. "The Human Resource Architecture: Toward a Theory of Human Capital Allocation and Development." The Academy of Management Review 24 (1): 31-48. doi:10.2307/259035.

Lévesque, Moren, Maria Minniti, and Dean Shepherd. 2009. “Entrepreneurs' Decisions on Timing of Entry: Learning from Participation and from the Experiences of Others."'Entrepreneurship Theory and Practice 33 (2): 547-570. doi:10.1111/j.1540-6520.2009.00303.x.

Lightfoot, Howard, Tim Baines, and Palie Smart. 2013. "The Servitization of Manufacturing: A Systematic Literature Review of Interdependent Trends." International Journal of Operations \& Production Management 33 (11/12): 14081434. doi:10.1108/IJOPM-07-2010-0196.

Lindsay, Noel. 2012. "Avatars Not Just for Movies." Public Administration Today (31): 19.

Madhok, A. 2002. "Reassessing the Fundamentals and beyond: Ronald Coase, the Transaction Cost and Resource-Based Theories of the Firm and the Institutional Structure of Production." Strategic Management Journal 23: 535-550.

Man, Thomas W. Y., and Theresa Lau. 2005. "The Context of Entrepreneurship in Hong Kong: An Investigation through the Patterns of Entrepreneurial Competencies in Contrasting Industrial Environments." Journal of Small Business and Enterprise Development 12 (4): 464-481. doi:10.1108/14626000510628162.

Maritz, Alex, and Christopher R. Brown. 2013."Illuminating the Black Box of Entrepreneurship Education Programs." Education + Training 55 (3): 234-252. doi:10.1108/00400911311309305.

Maritz, Alex, Colin Jones, and Claudia Shwetzer. 2015. "The Status of Entrepreneurship Education in Australian Universities." Education + Training 57 (8/9): 1020-1035. doi:10.1108/ET-04-2015-0026.

Martin, Bruce C., Jeffrey J. McNally, and Michael J. Kay. 2013. "Examining the Formation of Human Capital in Entrepreneurship: A Meta-Analysis of Entrepreneurship Education Outcomes." Journal of Business Venturing 28 (2): 211224. doi:10.1016/j.jbusvent.2012.03.002. 
Marvel, Matthew R., and G. T. Lumpkin. 2007.“Technology Entrepreneurs' Human Capital and Its Effects on Innovation Radicalness." Entrepreneurship Theoryand Practice 31 (6): 807-828. doi:10.1111/j.1540- 6520.2007.00209.x.

Matlay, Harry. 2009. "Entrepreneurship Education in the UK: A Critical Analysis of Stakeholder Involvement and Expectations."Journal of Small Business and Enterprise Development 16 (2): 355-368. doi:10.1108/14626000910956100.

Matlay, H. 2016. "Entrepreneurship Education in Asia." Education + Training 58 (7/8): 899-900. doi:10.1108/ET-06-2016-0104.

Miles, Morgan P., Huibert de Vries, Geoff Harrison, Martin Bliemel, Saskia de Klerk, and Chick J. Kasouf. 2017. "Accelerators as Authentic Training Experiences for Nascent Entrepreneurs." Education + Training 59 (7/8): 811-824. doi:10.1108/ET01-2017-0007.

Miller, Paul, and Kirsten Bound. 2011. The Startup Factories: The Rise of Accelerator Programmes to Support New Technology Ventures. Nesta.

MOHE. 2010. Development of Higher Education Institute Entrepreneurship Foundation. Putrajaya: Ministry of Higher Education Malaysia.

Moore, Geoffrey A. 1999. Crossing the Chasm. 2nd ed. Oxford: Capstone.

Neck, Heidi M., and Patricia G. Greene. 2011. "Entrepreneurship Education: Known Worlds and New Frontiers."Journal of Small Business Management 49 (1): 55-70. doi:10.1111/j.1540-627X.2010.00314.x.

Neck, Heidi M. 2014. Teaching Entrepreneurship: A Practice-Based Approach. Cheltenham: Edward Elgar Pub.

Nielsen, Suna Løwe, and Stovang Pia. 2015. "DesUni: University Entrepreneurship Education through Design Thinking." Education + Training 57 (8/9): 977-991. doi:10.1108/ET-09-2014-0121.

Norasmah, Othman, and Nasrudin Norfadhilah. 2016. "Entrepreneurship Education Programs in Malaysian Polytechnics." Education + Training 58 (7/8): 882-898. doi:10.1108/ET-11-2014-0136.

Norfadhilah, Nasrudin. 2014. "Penilaian Pencapaian Objektif Program Pembudayaan Keusahawanan (PPK) Di Politeknik Malaysia.” Universiti Kebangsaan.

O’Connor, Allan. 2013. "A Conceptual Framework for Entrepreneurship Education Policy: Meeting Government and Economic Purposes.” Journal of Business Venturing 28 (4): 546-563. doi:10.1016/j. jbusvent.2012.07.003.

O’Connell, B. 2011. "Start X: Training Ground for Stanford's Best and Brightest." Kauffman Foundation.

O'Connor, A., and G. Reed. 2015. South Australia's Entrepreneurial Ecosystem: Voice of the Customer Research Report', Report Prepared for the SA Government Department of State Development by the Entrepreneurship. Commercialisation and Innovation Centre (ECIC), University of Adelaide.

O'Connor, Kevin B., and Robert John Stimson. 1995. The Economic Role of Cities: Economic Change and City Development, Australia 1971-1991. Australian Government Pub. Service.

Osterwalder, Alexander. 2004. "The Business Model Ontology - A Proposition in a Design Science Approach.” Doctoral Thesis, University of Lausanne, Lausanne, Switzerland.

Osterwalder, Alexander. 2012."Business Model Canvas: A Simple Tool for Designing Innovative Business Models." Forbes Magazine.

Othman, Norasmah, and Norfadhilah Nasrudin. 2016. "Entrepreneurship Education Programs in Malaysian Polytechnics." Education + Training 58 (7/8): 882-898. doi:10.1108/ET-11-2014-0136. 
Ozgen, Eren, and Robert A. Baron. 2007. "Social Sources of Information in Opportunity Recognition: Effects of Mentors, Industry Networks, and Professional Forums." Journal of Business Venturing 22 (2): 174-192. doi:10.1016/j.jbusvent.2005.12.001.

Perkmann, M., and K. Walsh. 2007.“University-Industry Relationships and Open Innovation: Towards a Research Agenda (Review Article)." International Journal of Management Reviews 9: 259-280.

Pittaway, L. A. 2004."Simulating Entrepreneurial Learning: Assessing the Utility of Experiential Learning Designs.” Lancaster University Management School Working Paper, 1-33.

Pittaway, Luke, and Jason Cope. 2007. "Entrepreneurship Education: A Systematic Review of the Evidence.” International Small Business Journal 25 (5): 479-510. Radojevich-Kelley, Nina, and David Lynn Hoffman. 2012. "Analysis of Accelerator Companies: An Exploratory Case Study of Their Programs, Processes, and Early Results." Small Business Institute Journal 8 (2): 54-70.

Rae, David M. 1997. "Teaching Entrepreneurship in Asia: Impact of a Pedagogical Innovation." Entrepreneurship, Innovation and Change 6 (3): 193-227.

Rae, David. 2012. “Action Learning in New Creative Ventures." International Journal of Entrepreneurial Behavior \& Research 18 (5): 603-623. doi:10.1108/13552551211253955.

Redding, Gordon, and Chris Rowley. 2017."Conclusion: The Central Role of Human and Social Capital.” Asia Pacific Business Review 23 (2): 299-305. doi:10.1080/13602381.2017.1289033.

Ries, Eric. 2011. The Lean Startup: How Today's Entrepreneurs Use Continuous Innovation to Create Radically Successful Businesses. Crown Books.

Robinson, Peter B., Jonathan C. Huefner, and H. Keith Hunt. 1991."Entrepreneurial Research on Student Subjects Does Not Generalize to Real World Entrepreneurs." Journal of Small Business Management 29 (2): 42-50.

Ronstadt, R.. 1987.“The Educated Entrepreneurs: A New Era of Entrepreneurial Education is Beginning." American Journal of Small Business 11 (4): 37-54.

Ronstadt, Robert, Karl H. Vesper, and W.Ed. McMullan. 1988. “Entrepreneurship: Today Courses, Tomorrow Degrees?" Entrepreneurship Theory and Practice 13 (1): 7-13. doi:10.1177/104225878801300102.

Roos, G. 2012. Manufacturing into the Future. Adelaide: Adelaide Thinkers-inResidence Office, Government of South Australia.

Roos, Göran. 2015. "Servitization as Innovation in Manufacturing - A Review of the Literature.” In The Handbook of Service Innovation, edited by Renu Agarwal, Willem Selen, Göran Roos and Roy Green, 403-435. London: Springer.

Roos, G., A. Bainbridge, and K. Jacobsen. 2001."Intellectual Capital Analysis as a Strategic Tool."Strategy \& Leadership 29 (4): 21-26.

Roos, G., S. Pike, and L. Fernstrom. 2005. Managing Intellectual Capital in Practice. London: Routledge. Rubin, Herbert J., and Irene S. Rubin. 2011. Qualitative Interviewing: The Art of Hearing Data. Los Angeles, CA: Sage.

Rutherfurd, I. A. N., and Brian Finlayson. 2011. "Whither Australia: Will Availability of Water Constrain the Growth of Australia's Population?" Geographical Research 49 (3): 301-316. doi:10.1111/j.1745- 5871.2011.00707.x.

Saldana, Johnny. 2009. The Coding Manual for Qualitative Researchers. London: SAGE Publications.

Seely-Brown, J., and P. Duguid. 2001. "Knowledge and Organization: A SocialPractice Perspective.”Organization Science 12 (2): 198-213. 
Seet, Pi-Shen. 2007. "Reconciling Entrepreneurial Dilemmas - A Case Study of a Huaqiao (华侨) Entrepreneur in China.” Journal of Asia Entrepreneurship and Sustainability 3 (3): 75-97.

Seet, Pi-Shen, and Lip-Chai Seet. 2006. "Changing Entrepreneurial Perceptions and Developing Entrepreneurial Competencies through Experiential Learning: Evidence from Entrepreneurship Education in Singapore's Tertiary Education Institutions." Journal of Asia Entrepreneurship and Sustainability 2 (2): 162-191.

Sepulveda, Fernando. 2012."The Difference between a Business Accelerator and a Business Incubator?" Inc. Web, 31.

Shane, Scott, and S. Venkataraman. 2000. "The Promise of Entrepreneurship as a Field of Research."Academy of Management Review 25 (1): 217-226.

Shen, Joan. 2014. "Recent Development on Start-up Acceleration and Business Continuity Planning in APEC Region." Editorial Statement, 21.

Shepherd, D. A., and A. Zacharakis. 2001. "Speed to Initial Public Offering of VCBacked Companies." Entrepreneurship Theory and Practice 25: 59.

Shrader, Rod, and Donald S. Siegel. 2007."Assessing the Relationship between Human Capital and Firm Performance: Evidence from Technology-Based New Ventures."Entrepreneurship Theory and Practice 31 (6): 893-908. doi:10.1111/j.1540-6520.2007.00206.x.

Singh, Robert Paul. 2000. Entrepreneurial Opportunity Recognition through Social Networks. New York: Garland Publishing.

Singh, Robert P., Gerald E. Hills, G. T. Lumpkin, and Ralph C. Hybels. 1999. The Entrepreneurial Opportunity Recognition Process: Examining the Role of Self-Perceived Alertness and Social Networks. Paper presented at the Academy of Management Proceedings.

Solesvik, Marina, Paul Westhead, and Harry Matlay. 2014."Cultural Factors and Entrepreneurial Intention: The Role of Entrepreneurship Education." Education + Training 56 (8/9): 680-696. doi:10.1108/ET- 07-2014-0075.

Solomon, George T., Susan Duffy, and Ayman Tarabishy. 2002."The State of Entrepreneurship Education in the United States: A Nationwide Survey and Analysis." International Journal of Entrepreneurship Education 1 (1): 65-86.

Sosa, Manuel E. 2011."Where Do Creative Interactions Come from? The Role of Tie Content and Social Networks." Organization Science 22 (1): 1-21. doi:10.1287/orsc.1090.0519.

Stam, Wouter, Souren Arzlanian, and Tom Elfring. 2014."Social Capital of Entrepreneurs and Small Firm Performance: A Meta-Analysis of Contextual and Methodological Moderators." Journal of Business Venturing 29 (1): 152-173. doi:10.1016/j.jbusvent.2013.01.002.

St-Jean, Étienne, and Cynthia Mathieu. 2015. "Developing Attitudes toward an Entrepreneurial Career through Mentoring: The Mediating Role of Entrepreneurial Self-Efficacy." Journal of Career Development 42 (4): 325-338. doi:10.1177/0894845314568190.

St-Jean, Étienne, Maripier Tremblay, Frank Janssen, Jacques Baronet, Christophe Loué, and Aziz Nafa. 2017."May Business Mentors Act as Opportunity Brokers and Enablers among University Students?" International Entrepreneurship and Management Journal 13 (1): 97-111. doi:10.1007/s11365-016-0397-4.

Stokes, David, Nicholas Wilson, and Nick Wilson. 2010. Small Business Management and Entrepreneurship. Cengage Learning EMEA.

Stross, Randall. 2013. The Launch Pad: Inside Y Combinator. London: Penguin. 
Sullivan, Robert. 2000.“Entrepreneurial Learning and Mentoring."International Journal of Entrepreneurial Behavior \& Research 6 (3): 160-175. doi:10.1108/13552550010346587.

Sun, Hongyi, Choi Tung Lo, Bo Liang, and Yuen Ling Belle Wong. 2017."The Impact of Entrepreneurial Education on Entrepreneurial Intention of Engineering Students in Hong Kong." Management Decision 55 (7): 1371-1393. doi:10.1108/MD-06-20160392.

Sung-Choon, Kang, Shad S. Morris, and Scott A. Snell. 2007. "Relational Archetypes, Organizational Learning, and Value Creation: Extending the Human Resource Architecture." The Academy of Management Review 32 (1): 236-256. doi: $10.2307 / 20159290$.

Tharenou, Phyllis, and Pi-Shen Seet. 2014. "China's Reverse Brain Drain." International Studies of Management \& Organization 44 (2): 55-74. doi:10.2753/IMO0020-8825440203.

Unger, Jens M., Andreas Rauch, Michael Frese, and Nina Rosenbusch. 2011. "Human Capital and Entrepreneurial Success: A Meta-Analytical Review." Journal of Business Venturing 26 (3): 341-358. doi:10.1016/j.jbusvent.2009.09.004.

Vanhonacker, W. R., D. Zweig, and S. F. Chung. 2006. Transnational or social capital? Returnee versus local entrepreneurs. China's Domestic Private Firms: Multidisciplinary Perspectives on Management and Performance.

Walmsley, D. J., and H. C. Weinand. 1997."Is Australia Becoming More Unequal?"Australian Geographer 28 (1): 69-88. doi:10.1080/00049189708703181. Wright, Mike, Keith M. Hmieleski, Donald S. Siegel, and Michael D. Ensley. 2007. "The Role of Human Capital in Technological Entrepreneurship." Entrepreneurship Theory and Practice 31 (6): 791-806. doi:10.1111/j.1540-6520.2007.00202.x.

Youndt, Mark A., Mohan Subramaniam, and Scott A. Snell. 2004. "Intellectual Capital Profiles: An Examination of Investments and Returns*." Journal of Management Studies 41 (2): 335-361. doi:10.1111/j.1467-6486.2004.00435.x.

Zacharakis, Andrew L., and G. Dale Meyer. 2000."The Potential of Actuarial Decision Models: Can They Improve the Venture Capital Investment Decision?" Journal of Business Venturing 15 (4): 323-346.

Zhao, Hongxin, and Jiangyong Lu. 2016.“Contingent Value of Political Capital in Bank Loan Acquisition: Evidence from Founder-Controlled Private Enterprises in China."Journal of Business Venturing 31 (2): 153-174. doi:10.1016/j.jbusvent.2015.12.002.

Zhao, Xiang-yang, Michael Frese, and Angelo Giardini. 2010. "Business Owners' Network Size and Business Growth in China: The Role of Comprehensive Social Competency." Entrepreneurship \& Regional Development 22 (7-8): 675-705. doi:10.1080/08985620903171376.

Zijdemans, Erik, and Stoyan Tanev. 2014.“Conceptualizing Innovation in Born-Global Firms.’Technology Innovation Management Review 4 (9): 5-10. 


\section{FIGURES AND TABLES}

Figure 1 - Relationship of Contemporary Content

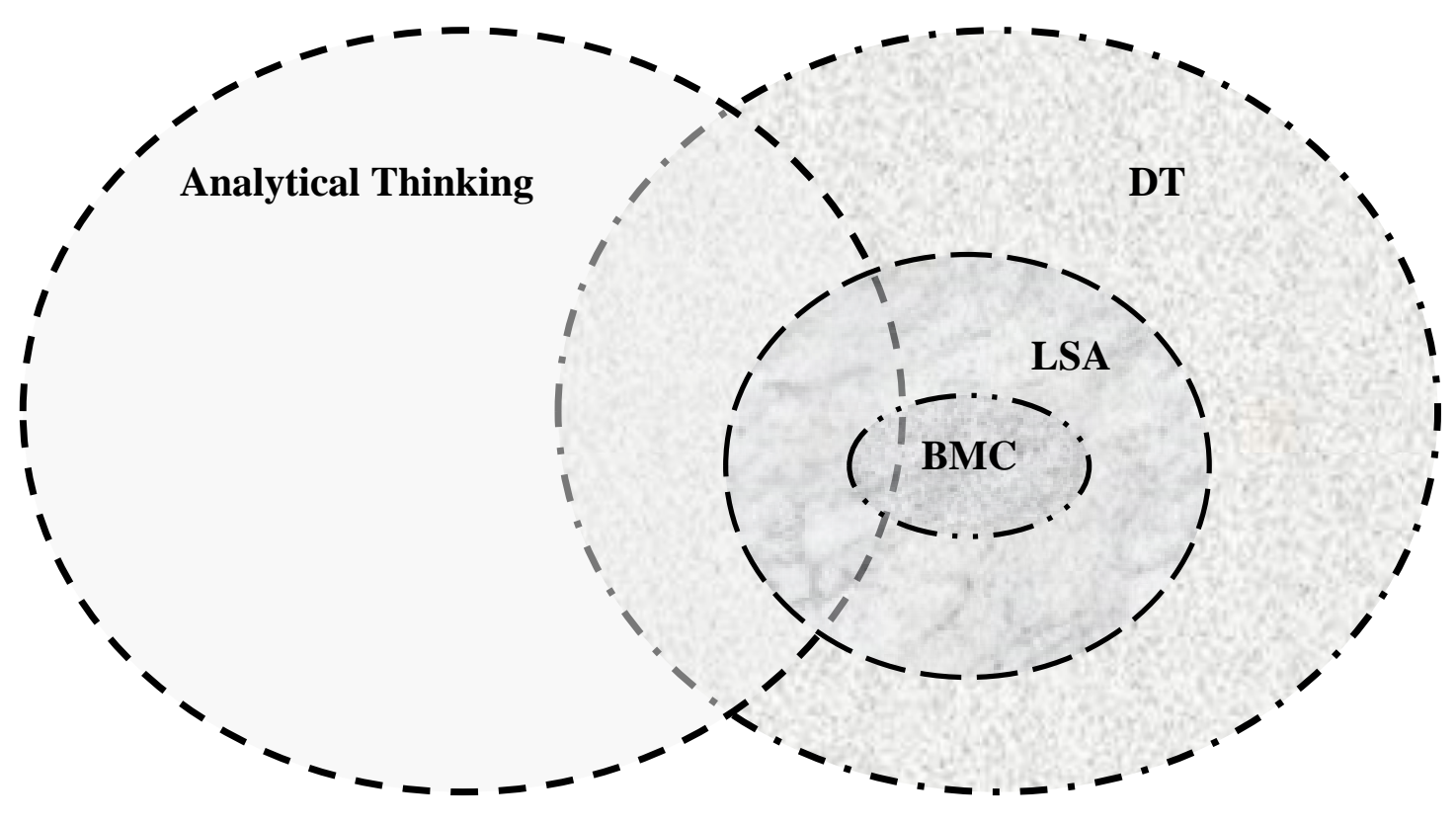


Table 1 - Startup Accelerators vs Traditional Incubators

\begin{tabular}{|l|l|l|}
\hline & Startup Accelerators & Incubators \\
\hline Duration & Fixed short term (3 months average) & Fixed long term (1-5 years) \\
\hline Selection & Competitive, cyclical & Non-competitive \\
\hline Education & Formal & Ad hoc \\
\hline Mentorship & Intense, by self and others & Minimal, as needed \\
\hline
\end{tabular}


Table 2 - Traditional Content

\begin{tabular}{|c|c|}
\hline Type & Reference \\
\hline $\begin{array}{l}\text { Entrepreneurial } \\
\text { Self-Efficacy }\end{array}$ & $\begin{array}{l}\text { Bandura (1991) } \\
\text { Ajzen (1991) } \\
\text { Fayolle (1996 and 2002) } \\
\text { Fayolle and Gailly (2008) } \\
\text { Rae (2012) }\end{array}$ \\
\hline $\begin{array}{l}\text { Entrepreneurial Skills } \\
\text { - } \text { Business Planning } \\
\text { - } \text { Business Law } \\
\text { - } \text { Marketing } \\
\text { - } \text { Production } \\
\text { - } \text { Product Design }\end{array}$ & $\begin{array}{l}\text { Vesper and McMullen (1988) } \\
\text { Hills (1988) } \\
\text { Bygrave (1994 and 1997) } \\
\text { Gibb (1997) } \\
\text { Rae (1997) } \\
\text { Gorman et al (1997) } \\
\text { Jack and Anderson (1999) } \\
\text { Fiet (2001a and 2001b) } \\
\text { Honig and Karlsson (2004) } \\
\text { Kuratko (2003 and 2005) }\end{array}$ \\
\hline Entrepreneurial Finance & $\begin{array}{l}\text { Ronstadt, Vesper, and McMullan (1988) } \\
\text { Cohen and Levinthal (1990) } \\
\text { Shepherd and Zacharakis (2001, 2002) } \\
\text { Kuratko (2005) } \\
\text { Dimov and Shepherd (2005) } \\
\text { Rae (2012) }\end{array}$ \\
\hline
\end{tabular}


Table 3 - Contemporary Content

\begin{tabular}{|l|l|}
\hline Type & Reference \\
\hline Design Thinking & Neck et al (2014) \\
\hline Business Model Canvas & Osterwalder (2004) \\
\hline Lean Startup approach & Eisenmann et al (2012) \\
\hline Validation & Rae (2012) \\
\hline
\end{tabular}


Table 4 - Participant Profiles

\begin{tabular}{|c|c|c|c|}
\hline Participant & Gender & $\begin{array}{l}\text { Completed } \\
\text { Program }\end{array}$ & Experience \\
\hline E1 & $\mathrm{F}$ & $\mathrm{Y}$ & No-Student \\
\hline $\mathbf{E 2}$ & $\mathrm{M}$ & $\mathrm{Y}$ & No - Student \\
\hline $\mathbf{E 3}$ & $\mathrm{F}$ & $\mathrm{Y}$ & No \\
\hline $\mathbf{E 4}$ & $\mathrm{F}$ & $\mathrm{Y}$ & No \\
\hline $\mathbf{E 5}$ & M & $\mathrm{Y}$ & Yes - Founder of previous businesses \\
\hline E6 & $\mathrm{M}$ & $\mathrm{Y}$ & Medium - Been involved with start-ups \\
\hline E7 & $\mathrm{M}$ & $\mathrm{Y}$ & $\begin{array}{l}\text { Yes - Been involved starting and } \\
\text { managing other start-ups }\end{array}$ \\
\hline $\mathbf{E 8}$ & $\mathrm{M}$ & $\mathrm{Y}$ & No \\
\hline E9 & M & $\mathrm{Y}$ & Medium - Run unrelated business \\
\hline E10 & $\mathrm{M}$ & $\mathrm{Y}$ & Medium - career experience in industry \\
\hline E11 & M & $\mathrm{Y}$ & No - Student \\
\hline E12 & $\mathrm{M}$ & $\mathrm{Y}$ & No \\
\hline E13 & $\mathrm{F}$ & $\mathrm{Y}$ & No \\
\hline E14 & $\mathrm{M}$ & $\mathrm{Y}$ & No \\
\hline E15 & M & $\mathrm{N}-$ Current & $\begin{array}{l}\text { Yes - Manages business and been } \\
\text { involved in starting new ventures }\end{array}$ \\
\hline E16 & $\mathrm{M}$ & $\mathrm{N}-$ Current & No \\
\hline E17 & $\mathrm{M}$ & $\mathrm{N}-$ Current & No \\
\hline E18 & $\mathrm{F}$ & $\mathrm{N}-$ Current & No \\
\hline E19 & $\mathrm{M}$ & $\mathrm{N}-$ Current & Yes - Started new ventures before \\
\hline E20 & $\mathrm{M}$ & $\mathrm{N}$ - Current & No \\
\hline
\end{tabular}




\section{Table 5 - Business Model Canvas}

\begin{tabular}{|c|c|}
\hline Interviewee & Interviewees' quotes \\
\hline E11 & $\begin{array}{l}\text { "I have a much broader idea of how it's all going to come together } \\
\text { and taking action to pull it about and put it together again." }\end{array}$ \\
\hline E18 & $\begin{array}{l}\text { "It goes back to that business model canvas, everything within that I } \\
\text { am just honing in on and unpacking. You know how to identify the } \\
\text { right channels, who the target market is, who they look like, how to } \\
\text { personify them, the archetype of that person, linking values to the } \\
\text { value proposition and to the customer segment, recognising that there } \\
\text { is different customer segments and different revenue models. It's an } \\
\text { invaluable process for me." }\end{array}$ \\
\hline E10 & $\begin{array}{l}\text { "With the business model canvas and going through it in such a } \\
\text { formulaic way, each week they'd focus on a particular aspect and the } \\
\text { problem with that is that everyone had actually come in to this in } \\
\text { varying levels and some people were individuals some people were } \\
\text { groups and I had something already developed. So, different people, } \\
\text { different points and each week you're expected to do their } \\
\text { concentrated on a particular aspect and that didn't match up with } \\
\text { everyone." }\end{array}$ \\
\hline
\end{tabular}


Table 6 - Minimal Viable Product

\begin{tabular}{|c|c|}
\hline Interviewee & Interviewees' quotes \\
\hline $\mathbf{E 4}$ & $\begin{array}{l}\text { "Definitely the minimum viable product, so that is getting the base } \\
\text { idea up and running as quickly as possible so you can get that real } \\
\text { world feedback. A lot of people spend a lot of time and money } \\
\text { producing something and then they put it out there and it doesn't take. } \\
\text { So it is important to get that really simple base idea and get the } \\
\text { feedback and work on it and go from there." }\end{array}$ \\
\hline E1 & $\begin{array}{l}\text { "We realised we had to make it smaller and get our minimal viable } \\
\text { product out there and selling it to people, and that wasn't possible } \\
\text { with our original idea, it was just way to big and way to complex." }\end{array}$ \\
\hline E5 & $\begin{array}{l}\text { "The minimal viable product and talking to customers is the core of } \\
\text { the lean start-up approach, and then looking at all the different kinds } \\
\text { of revenue streams and types of partnerships you can have and the } \\
\text { different structures of the company you can have." }\end{array}$ \\
\hline
\end{tabular}




\section{Table 7 - Validation}

\begin{tabular}{|c|c|}
\hline Interviewee & Interviewees' quotes \\
\hline E6 & $\begin{array}{l}\text { "I think the main thing would definitely be a cheaper way to validate } \\
\text { the business model. That's the first thing I got, there's a lot of different } \\
\text { ways you can find out if the model is right. The second is when I'm } \\
\text { starting a business it is all based on assumptions and I need to do } \\
\text { validate those assumptions, that is what the EEP taught me." }\end{array}$ \\
\hline E8 & $\begin{array}{l}\text { "Rather than learning from experience the whole process has been } \\
\text { accelerated into } 12 \text { weeks and I could validate all assumptions about } \\
\text { my business model in } 12 \text { weeks." }\end{array}$ \\
\hline
\end{tabular}


Table 8 - Mentors and Mentorship

\begin{tabular}{|c|c|}
\hline Interviewee & Interviewees' quotes \\
\hline E3a & $\begin{array}{l}\text { "Making networks and contacts and being able to pick the brains of } \\
\text { people who have been there and done that, and getting their insights. } \\
\text { That was the most valuable part, people who knew about } \\
\text { entrepreneurship and who have been there and were able to give me } \\
\text { really sound advice." }\end{array}$ \\
\hline E2 & $\begin{array}{l}\text { "Mentors that were there or mentors and professionals that were there } \\
\text { each week they were probably the key learning resources providing } \\
\text { professional experience and advice on problems that we were having." }\end{array}$ \\
\hline $\mathbf{E 3 b}$ & $\begin{array}{l}\text { "...Getting onto our personal mentors a lot earlier would have been } \\
\text { good as it took a while and the selection of the mentors to match } \\
\text { personality as well as the project and the expertise of the mentors...." }\end{array}$ \\
\hline
\end{tabular}




\section{Table 9 - Experts}

\begin{tabular}{|c|c|}
\hline Interviewee & Interviewees' quotes \\
\hline E10a & $\begin{array}{l}\text { "The other thing I found valuable and helpful is that they brought } \\
\text { specialists in, for example; in Law or SEO and design. Especially for } \\
\text { the people who weren't so techy or design focussed." }\end{array}$ \\
\hline E15 & $\begin{array}{l}\text { "It's always its good having people there I made some new } \\
\text { connections in regard to IP so that's been some really good value and } \\
\text { input I've got so far." }\end{array}$ \\
\hline E12 & $\begin{array}{l}\text { "it was useful in introducing me to a couple useful people in the } \\
\text { community that could help with legal matters and that sort of thing } \\
\text { which is useful." }\end{array}$ \\
\hline E9 & $\begin{array}{l}\text { "With the TAFE programs you get some of this MVP happening via } \\
\text { website development which is really good. But having said that the } \\
\text { process still is very piece mill... ....it gets cut off to quickly and you } \\
\text { have to hand that process on to another group and it then takes some } \\
\text { time for that group to get their head around what they were doing." }\end{array}$ \\
\hline E10b & $\begin{array}{l}\text { ".... Whereas if this program had a marketing person come in and all } \\
\text { those different skill sets and were willing to do that you would actually } \\
\text { pump out some teams that would have a bit of sound business } \\
\text { knowledge, know how to market, test a product or idea...” }\end{array}$ \\
\hline
\end{tabular}


Table 10 - Peers

\begin{tabular}{|l|l|}
\hline Interviewee & \multicolumn{1}{c}{ Interviewees' quotes } \\
\hline $\mathbf{E 2}$ & $\begin{array}{l}\text { "Learning from our peers was valuable as these people were in the } \\
\text { same situation as us and they had the same problems as us. Also, they } \\
\text { werults and getting really far down the track really fast." }\end{array}$ \\
\hline $\begin{array}{l}\text { E4 } 4 \\
\text { "The peers, you learn from them but it also sets the benchmark and bit more to achieve what your trying to achieve, it's not } \\
\text { competition but it keeps you up to speed. Being held accountable each } \\
\text { week for having done the homework and progressing your idea, it kind } \\
\text { of pushed you forward and forced you to move forward. I think if } \\
\text { you're by yourself you can just linger on things for a long time" }\end{array}$ \\
\hline
\end{tabular}


Table 11 - Potential Customers and Stakeholders

\begin{tabular}{|c|c|}
\hline Interviewee & Interviewees' quotes \\
\hline $\mathbf{E 2}$ & $\begin{array}{l}\text { "The way we learnt the most was probably getting out there and } \\
\text { talking to people, that was the biggest thing. All the other mediums, the } \\
\text { videos, mentors and peers pushed us to doing this.", }\end{array}$ \\
\hline E20 & $\begin{array}{l}\text { "I would say talking to the customer. Yeah. Before being in the } \\
\text { program I was in my own head, what it was going to be like and } \\
\text { creating, I wasn't basing it on feedback, it was kind of the other way } \\
\text { around. You have to start from the customer. }\end{array}$ \\
\hline E12 & $\begin{array}{l}\text { "It forces you on a week to week basis to go well who is your } \\
\text { customer? Are they really who you think they are? So just going } \\
\text { through the process is helpful. It actually forced you to get out and } \\
\text { challenge or test your assumptions about what your customers want or } \\
\text { what they need or who they are were challenged by talking about it } \\
\text { with the group then talking with customers." }\end{array}$ \\
\hline
\end{tabular}

